\title{
European Briefing: Research and Development
}

Fifth Framework Programme

On an initiative by Commissioner

Edith Cresson, the European Commission

has determined guidelines and the overall content of its forthcoming proposal for the Fifth Research and Technological Development Framework Programme that will take effect in 1999. The paper confirms the Commission's intentions of organising the programme into six major parts: three "thematic" ones (life sciences and the ecosystem, information society, competitive and sustainable growth) and three "horizontal" programmes (international cooperation, innovation and participation of SMEs, improvement of human potential). The fifth framework programme should mark a break with earlier programmes. It should reflect a "desire to focus European research efforts on a small number of topics to tie in with key economic and social needs". Support for research infrastructures in Europe would be reassessed. The aim is greater flexibility and the budget will be released gradually, in response to unforseen needs. This working paper and an assessment report on present research activities will form the basis of the Commission's formal proposal for the programme. The assessment report will be drawn up by the Davignon expert group.The next Research Council will meet on 14. May and the Commission expects the fifth framework programme to be formally adopted in the Spring of 1998 . First calls for proposals will be issued end of 1998 and the projects will start early in 1999. But, since the perspectives for the EU budget after 1999 will not be set until that year, the fifth framework programme budget runs the risk of unpredictability.

\section{Davignon Group}

The report on the evaluation of European research filed by this expert group states that the EU framework programme is neither fulfilling its promise nor achieving its objectives. In its current form the programme is not flexible enough and not oriented towards EU policies, representing a compromise on national and sectoral aims. With the fifth framework programme "the time for a qualitative leap and a fundamental change has come - it must be more ambitious".

Member States are more reluctant today to invest in European research than they were in 1984, the inception of the framework programme, and competitive pressure on companies obliges them to focus their efforts on research close to the market. It is notable that budgetary commitment to research is dropping in Europe whilst rising in Japan and stable in the US. Continual arbitration between Member State interests during decisionmaking constitute complete discontinuity with normal best practice. Consequently the group recommends a change in decision-making structures and more flexible procedures, outlined in three essential modifications:

1) Majority voting in Council - by political agreement, without awaiting formal ratification

2) Flexibility in the choice of priorities and allocation of funds - commitment during implementation of the programme, allowing room for emergent disciplines 3) Centralised management under the Commission's responsibility - an end to permanent negotiation.

A pragmatic approach should make an equilibrium possible between basic and applied research; and users' needs should take precedence.

The report was based on an appraisal of the framework programme's working results over the last five years.

\section{Strasbourg, France: EP Demands} more Money for Research

The European Parliament has criticised EU governments for refusing to accept a substantial increase in EU funding for research and technological development (RTD) over the next two years. The parliament supports a European Commission recommendation for a 700 million ecu increase in the budget of the EU forth framework programme (19941998). But EU ministers are only prepared to allocate an extra 100 million ecu, to prevent the EU overall budget from surpassing its fixed ceiling. Parliament insists that a 200 million ecu increase is the minimun acceptable.

Euro-MPs said the increases should be

allocated to a new research programme on renewable energy ( 33 milliom ecu) and to doubling the funds for existing programmes on telematics, information technology, industrial and materials technology, the environment and climate change.

Parliament requested a further 20 million ecu for research on the detection and destruction of landmines.

The parliamentary report noted that of the 100 million ecu it was prepared to add to the research budget, Council had earmarked 35 million - over a third - for BSE research, vaccines and viral infections. Parliament conceded that research on BSE was essential because of the health hazards, but protested that the money should have been found elsewhere, rather than draining resources from other priority research areas. If, as seems likely, Council refuses to accept Parliament's amendments to the text, the two sides will have to embark on conciliation talks.

Reuters Ltd. 1997

.... and Brussels' mores...

Soupe de - the menu for the Fifth Framework Programme

At the end of February a convocation of Europe's finest acronyms gathered in Brussels for a first taste of the emerging plans for the 5 th. Framework Programme. This meal is not yet fully cooked, but the menu has been set and the main ingredients defined. Only the choice of garnishes remains to be determined by the European Parliament and others. The menu has the vertical/ horizontal matrix structure beloved of Brussels administrators. Vertically disposed are three main themes: resources of the living world; a user-friendly information society; competitive and sustainable growth; horizontally: international role of European research; innovation and SMEs; human potential. What does it all mean? Speaker after speaker called this a turning-point or new departure. We are to be directed towards "relevant research with clear objectives". While scientific excellence is acknowledged as a sine qua non, two other criteria loom large: relevance to social and economic policy; European added-value.The latter is not a tax; it is a conceived benefit of a European project as compared with individual national ones. Finally there was much talk of administrative flexibility, delegated responsibility and expeditious processes. On verra... These trends will come as no surprise to dedicated Brussels-watchers, or even the more short-sighted. A cold wind blows for basic research everywhere. It must find shelter under such terms as "generic technologies". Even within the targets defined above, there will be a tight focus in many areas. The argument runs that even such programmes as ESPRIT need this, because they are typically oversubscribed in terms of porposals by a factor of six. Would half of the proposers be happy to be excluded ab initio? Probably not, but the Commission would be a lot happier with less than the 24000 proposals it received in 1995 . Severe indigestion has prompted a leaner, meaner cuisine. While the Commission remains the key player in all of this, the Strasbourg parliamentarians play a role and are very approachable. Any pressure to boost basic science may well come from that direction. Remember also that only $7 \%$ reduction in the CAP could double the science budget. 